\title{
Acute supraglottitis during COVID-19 pandemic: by SARS-CoV-2 virus or not?
}

\author{
Yuh Baba ${ }^{1}$ and Yasumasa Kato ${ }^{1}$ \\ ${ }^{1} \mathrm{Ohu}$ University
}

May 5, 2020

\begin{abstract}
This clinical image indicates the importance of the early diagnosis and treatment of acute supraglottitis during COVID-19 pandemic.
\end{abstract}

\section{CASE REPORT}

A 46-years-old Japanese woman presented to our hospital with fever and dyspnea. On examination, her body temperature was $38.0^{\circ} \mathrm{C}$, blood pressure $114 / 79 \mathrm{~mm} \mathrm{Hg}$, heart rate 130 beats/min, respiratory rate 22 breaths/min, and oxygen saturation $97 \%$ breathing ambient room air. Her laboratory findings showed white blood cells count of 9,390 cells $/ \mathrm{mm}^{3}$, C-reactive protein $22.46 \mathrm{mg} / \mathrm{dL}$. Radiographic imaging of chest showed no pneumonia. Direct laryngoscopy showed right epiglottitis with inflammation and edema of the right aryepiglottic fold and arytenoid (Figure 1). Thus, we diagnosed this case as acute supraglottitis.

\section{QUESTION}

What is suspected as the pathogen of acute supraglottitis during COVID-19 pandemic?

\section{ANSWER}

At first, we took SARS-CoV-2 virus into consideration as one of causes of acute supraglottitis during COVID19 pandemic, as Tysome et al. indicated. ${ }^{1}$ However, in this case, the laryngoscopic findings did not show the ulceration nor overlying fibrinous exudate, which was seen in viral laryngitis, ${ }^{1,}{ }^{2}$ but show inflammation and edema, and blood test data was neutrophil predominance (85.5\%), suggesting that the case was not caused by virus, but bacteria, nervertheless during COVID-19 pandemic. After the judgement by us, the patient immediately received intravenous antibiotics, and she fortunately recovered from the illness without tracheostomy.

\section{DISCLOSURES}

Nones.

\section{INFORMED CONSENT}

Informed consent has been obtained for the publication of this clinical image from the patient.

CONFLICT OF INTEREST 
None declared.

\section{AUTHORSHIP}

All the authors made a substantial contribution to the preparation of this manuscript and approved the final version for submission. YB: Prepared the manuscript. YB and YK: Reviewed the manuscript and provided the clinical images.

\section{ORCID}

Yuh Baba iD https://orcid.org/0000-0002-1210-4670

\section{REFERENCES}

1. Tysome JR, Bhutta MF. COVID-19: Protecting our ENT workforce.Clin Otolaryngol. 2020; doi: 10.1111/coa.13542. Online ahead of print.

2. Dominguez LM, Simpson CB. Viral laryngitis: a mimic and a monster - range, presentation, management. Curr Opin Otolaryngol Head Neck Surg. 2015;23:454-458.

FIGURE 1 Direct laryngoscopy showed right epiglottitis with inflammation and edema of the right aryepiglottic fold and arytenoid

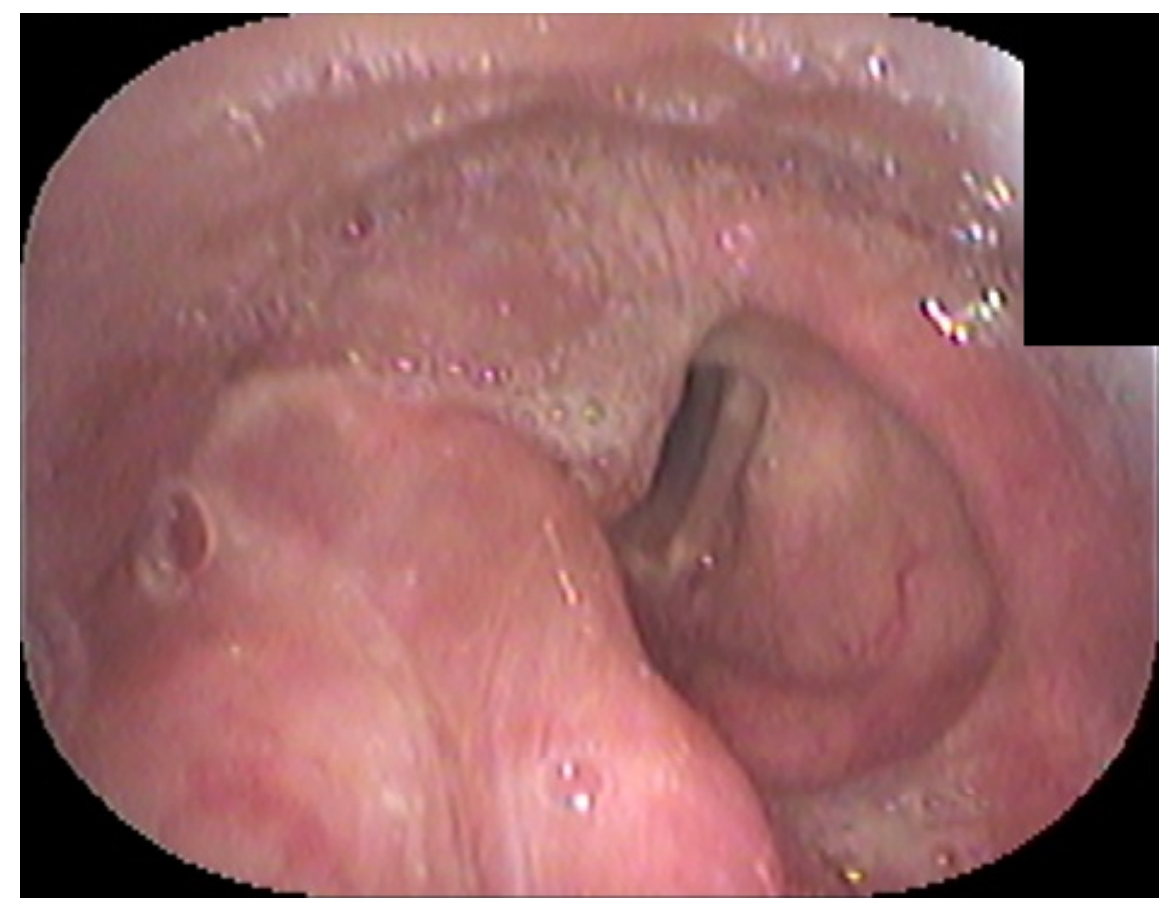

